\title{
Front Matter: Volume 8208
}

, "Front Matter: Volume 8208," Proc. SPIE 8208, Lasers in Dentistry XVIII, 820801 (19 March 2012); doi: 10.1117/12.927764

SPIE. Event: SPIE BiOS, 2012, San Francisco, California, United States 


\title{
PROGRESS IN BIOMEDICAL OPTICS AND IMAGING
}

Vol. 13, No. 2

\section{Lasers in Dentistry XVIII}

\author{
Peter Rechmann \\ Daniel Fried \\ Editors
}

22 January 2012

San Francisco, California, United States

Sponsored and Published by

SPIE

Volume 8208 
The papers included in this volume were part of the technical conference cited on the cover and title page. Papers were selected and subject to review by the editors and conference program committee. Some conference presentations may not be available for publication. The papers published in these proceedings reflect the work and thoughts of the authors and are published herein as submitted. The publisher is not responsible for the validity of the information or for any outcomes resulting from reliance thereon.

Please use the following format to cite material from this book:

Author(s), "Title of Paper," in Lasers in Dentistry XVIII, edited by Peter Rechmann, Daniel Fried, Proceedings of SPIE Vol. 8208 (SPIE, Bellingham, WA, 2012) Article CID Number.

ISSN $1605-7422$

ISBN 9780819488510

Published by

SPIE

P.O. Box 10, Bellingham, Washington 98227-0010 USA

Telephone +1 3606763290 (Pacific Time) · Fax +1 3606471445

SPIE.org

Copyright (C) 2012, Society of Photo-Optical Instrumentation Engineers.

Copying of material in this book for internal or personal use, or for the internal or personal use of specific clients, beyond the fair use provisions granted by the U.S. Copyright Law is authorized by SPIE subject to payment of copying fees. The Transactional Reporting Service base fee for this volume is $\$ 18.00$ per article (or portion thereof), which should be paid directly to the Copyright Clearance Center (CCC), 222 Rosewood Drive, Danvers, MA 01923. Payment may also be made electronically through CCC Online at copyright.com. Other copying for republication, resale, advertising or promotion, or any form of systematic or multiple reproduction of any material in this book is prohibited except with permission in writing from the publisher. The CCC fee code is 1605$7422 / 12 / \$ 18.00$.

Printed in the United States of America.

Publication of record for individual papers is online in the SPIE Digital Library.

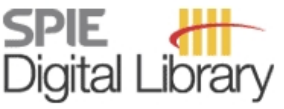

SPIEDigitalLibrary.org

Paper Numbering: Proceedings of SPIE follow an e-First publication model, with papers published first online and then in print and on CD-ROM. Papers are published as they are submitted and meet publication criteria. A unique, consistent, permanent citation identifier (CID) number is assigned to each article at the time of the first publication. Utilization of CIDs allows articles to be fully citable as soon as they are published online, and connects the same identifier to all online, print, and electronic versions of the publication. SPIE uses a six-digit CID article numbering system in which:

- The first four digits correspond to the SPIE volume number.

- The last two digits indicate publication order within the volume using a Base 36 numbering system employing both numerals and letters. These two-number sets start with 00, 01, 02, 03, 04, $05,06,07,08,09,0 A, 0 B \ldots$. 0Z, followed by 10-1Z, 20-2Z, etc.

The CID number appears on each page of the manuscript. The complete citation is used on the first page, and an abbreviated version on subsequent pages. Numbers in the index correspond to the last two digits of the six-digit CID number. 


\section{Contents}

vii Conference Committee

\section{SESSION 1 LASERS IN PERIODONTOLOGY AND SOFT TISSUE: TREATMENT AND DIAGNOSTICS}

820804 In-vivo gingival sulcus imaging using full-range, complex-conjugate-free, endoscopic spectral domain optical coherence tomography [8208-03]

Y. Huang, The Johns Hopkins Univ. (United States); K. Zhang, General Electric Global

Research Ctr. (United States); W. Yi, Seoul National Univ. School of Dentistry (Korea, Republic

of); J. U. Kang, The Johns Hopkins Univ. (United States)

\section{SESSION 2 LASERS AND COMPOSITES: BONDSTRENGTH AND DIAGNOSTICS}

820808 Shear bond strength of a self-etch adhesive to caries-affected dentin after caries removal by Er:YAG laser [8208-07]

Z. Zhan, Fujian Normal Univ. (China); W. Wu, Fujian Medical Univ. (China); H. Zhao, X. Zhang, Fujian Normal Univ. (China); S. Lin, Fujian Medical Univ. (China); S. Xie, Fujian Normal Univ. (China)

820809 Relationship between non-destructive OCT evaluation of resins composites and bond strength in a cavity [8208-08]

T. A. Bakhsh, Tokyo Medical and Dental Univ. (Japan) and King Abdulaziz Univ. (Saudi Arabia); A. Sadr, Y. Shimada, Tokyo Medical and Dental Univ. (Japan); S. Khunkar, Tokyo Medical and Dental Univ. (Japan) and King Abdulaziz Univ. (Saudi Arabia); J. Tagami, Tokyo Medical and Dental Univ. (Japan); Y. Sumi, National Ctr. for Geriatrics and Gerontology (Japan)

8208 OA Assessing ex vivo dental biofilms and in vivo composite restorations using cross-polarization optical coherence tomography [8208-09]

R. Jones, C. Aparicio, R. Chityala, R. Chen, A. Fok, J. Rudney, Univ. of Minnesota (United States)

\section{SESSION 3 LASER ABLATION, MODELLING, ENAMEL AND CARIES IMAGING}

8208 OB Particle characteristics of different materials after ultra-short pulsed laser (USPL) irradiation [8208-10]

J. Meister, F. Schelle, P. Kowalczyk, M. Frentzen, Bonn Univ. Dental Faculty (Germany)

8208 OC Modeling distributed feedback GaAs-based lasers in dentistry [8208-11]

M.-M. Shih, Univ. of Florida (United States)

8208 OD Investigations on the potential of a novel diode pumped Er:YAG laser system for dental applications [8208-12]

K. Stock, F. Hausladen, R. Hibst, Univ. Ulm (Germany) 
8208 OE Hyperspectral laser-induced autofluorescence imaging of dental caries [8208-13] M. Bürmen, A. Fidler, Univ. of Ljubljana (Slovenia); F. Pernuš, B. Likar, Univ. of Ljubljana (Slovenia) and Sensum, Computer Vision Systems (Slovenia)

8208 OF Spectrally enhanced image resolution of tooth enamel surfaces [8208-14] L. Zhang, L. Y. Nelson, J. H. Berg, E. J. Seibel, Univ. of Washington (United States)

\section{SESSION 4 LASERS IN EARLY CARIES DETECTION: MONITORING AND CARIES TREATMENT}

8208 OG Evaluation of cross-polarized near infrared hyperspectral imaging for early detection of dental caries [8208-15]

P. Usenik, M. Bürmen, A. Fidler, F. Pernuš, B. Likar, Univ. of Ljubljana (Slovenia)

$8208 \mathrm{OH} \quad$ Longitudinal assessment of subsurface artificial root caries lesions by optical coherence tomography in comparison with transverse microradiography [8208-16]

A. Sadr, S. Nakashima, Y. Shimada, J. Tagami, Tokyo Medical and Dental Univ. (Japan);

Y. Sumi, National Ctr. for Geriatrics and Gerontology (Japan)

$8208 \mathrm{Ol}$ Monitoring tooth demineralization using a cross polarization optical coherence tomographic system with an integrated MEMS scanner [8208-17]

D. Fried, M. Staninec, C. Darling, H. Kang, K. Chan, Univ. of California, San Francisco (United States)

8208 0J Transmission of $1064 \mathrm{~nm}$ laser radiation during ablation with an ultra-short pulse laser (USPL) system [8208-18]

F. Schelle, J. Meister, B. Oehme, M. Frentzen, Univ. Dental Clinic Bonn (Germany)

8208 OK Minimally invasive treatment of carious dentin with a nanosecond pulsed laser at $5.8 \mu \mathrm{m}$ wavelength [8208-19]

K. Ishii, M. Saiki, Osaka Univ. (Japan); K. Yoshikawa, K. Yasuo, K. Yamamoto, Osaka Dental

Univ. Hospital (Japan); K. Awazu, Osaka Univ. (Japan) and Univ. of Fukui (Japan)

\section{POSTER SESSION}

$82080 \mathrm{M}$ Relationship between refractive index and mineral content of enamel and dentin using SS-OCT and TMR [8208-21]

I. Hariri, A. Sadr, Y. Shimada, S. Nakashima, Tokyo Medical and Dental Univ. (Japan); Y. Sumi, National Ctr. for Geriatrics and Gerontology (Japan); J. Tagami, Tokyo Medical and Dental Univ. (Japan)

8208 OP Management of denture-induced epulis fissuratum with Er,Cr:YSGG laser: a case report [8208-24]

D. K. Koli, M. Gupta, M. Verma, A. K. Lamba, K. Chawla, Maulana Azad Institute of Dental Sciences (India)

$82080 Q$ Diffusion analysis of one photosensitizer in bovine teeth using fluorescence optical imaging [8208-25]

S. Montanha, Univ. Estadual Paulista (Brazil); S. Pratavieira, D. P. Jacomassi, Univ. of São Paulo (Brazil); A. N. S. Rastelli, Univ. of São Paulo (Brazil) and Univ. Estadual Paulista (Brazil); V. S. Bagnato, Univ. of São Paulo (Brazil) 
8208 OR Optical characterization of one dental composite resin using bovine enamel as reinforcing filler [8208-26]

J. T. Tribioli, D. Jacomassi, Univ. of São Paulo (Brazill); A. N. S. Rastelli, Univ. of São Paulo (Brazil) and Univ. Estadual Paulista (Brazil); S. Pratavieira, V. S. Bagnato, C. Kurachi, Univ. of São Paulo (Brazil)

8208 OT Low level laser intensity improves propulsive appliance effects on condylar cartilage [8208-28]

A. C. R. Figueiredo, F. C. A. dos Santos, L. R. Capeletti, M. V. B. Galdino, R. V. Araújo, M. R. Marques, Univ. Federal de Goias (Brazil)

$8208 \mathrm{OU}$ Selective removal of demineralization using near infrared cross polarization reflectance and a carbon dioxide laser [8208-29]

K. H. Chan, D. Fried, Univ. of California, San Francisco (United States)

8208 0V Remineralization of root caries monitored using cross polarization optical coherence tomography [8208-30]

C. L. Darling, M. Staninec, K. H. Chan, H. Kang, D. Fried, Univ. of California, San Francisco (United States)

$8208 \mathrm{OW}$ Investigation of acid-etched $\mathrm{CO}_{2}$ laser ablated enamel surfaces using polarization sensitive optical coherence tomography [8208-31]

B. J. Nahm, H. Kang, K. Chan, D. Fried, Univ. of California, San Francisco (United States)

$82080 \mathrm{X}$ Nondestructive monitoring of the repair of natural occlusal lesions using cross polarization optical coherence tomography [8208-32]

H. Kang, C. L. Darling, D. Fried, Univ. of California, San Francisco (United States)

Author Index 
Downloaded From: https://www.spiedigitallibrary.org/conference-proceedings-of-spie on 26 Apr 2023

Terms of Use: https://www.spiedigitallibrary.org/terms-of-use 


\title{
Conference Committee
}

\author{
Symposium Chairs
}

James G. Fujimoto, Massachusetts Institute of Technology

(United States)

R. Rox Anderson, Wellman Center for Photomedicine, Massachusetts

General Hospital, Harvard School of Medicine (United States)

Program Track Chair

Brian Jet-Fei Wong, Beckman Laser Institute and Medical Clinic

(United States)

Conference Chairs

Peter Rechmann, University of California, San Francisco (United States)

Daniel Fried, University of California, San Francisco (United States)

Program Committee

Gregory B. Altshuler, Palomar Medical Technologies, Inc.

(United States)

Tatjána Dostálová, Charles University in Prague (Czech Republic)

John D. Featherstone, University of California, San Francisco (United States)

David M. Harris, Bio-Medical Consultants, Inc. (United States)

Harvey A. Wigdor, Advocate Illinois Masonic Medical Center (United States)

Session Chairs

1 Lasers in Periodontology and Soft Tissue: Treatment and Diagnostics

Peter Rechmann, University of California, San Francisco (United States)

2 Lasers and Composites: Bondstrength and Diagnostics

Peter Rechmann, University of California, San Francisco (United States)

3 Laser Ablation, Modelling, Enamel and Caries Imaging

Daniel Fried, University of California, San Francisco (United States)

4 Lasers in Early Caries Detection: Monitoring and Caries Treatment

Daniel Fried, University of California, San Francisco (United States) 
Downloaded From: https://www.spiedigitallibrary.org/conference-proceedings-of-spie on 26 Apr 2023

Terms of Use: https://www.spiedigitallibrary.org/terms-of-use 